\title{
The Situation of 0-3 Years Old Temporarily Abandoned Children, in Romania, during 2003-2013 Causes, Consequences and Alternatives.
}

\author{
Rebeca Scorcia Popescu
}

\begin{abstract}
The present study analyzes the situation of children temporarily abandoned in Romania. Child abandonment does not occur only in Romania, but has some specific characteristics determined by the communist period, respectively by pronatalism followed by massive abandonment of children in orphanages. The lesson learned after years of communism led to investing in prevention methods and in the deinstitutionalization of children in the present, and there are different legislative provisions meant to help the families, especially the poor ones for preventing child abandonment. Despite these provisions child abandonment continues to be a current serious problem as the statistic of the Romanian Ministry of Labor shows: in 2013 4\% of the children between 0-3 years old were institutionalized in public placement centers. Considering that at the age of 0-3 years old, the effects of institutionalization are serious, because of the psychosocial characteristics specific to this age, it is considered important to approach this category of institutionalized children.
\end{abstract}

Index Terms-Abandonment of children in hospitals, child abandonment, institutionalization effects, maternal centre, Romania.

\section{INTRODUCTION}

In Romania children are abandoned usually by their own parents in different institutions. Sometimes they are left in a hospital unit, like maternity, but in the end the children will be in orphanages or foster care institutions. In very rare cases in Romania the children are left in inappropriate places which put them in grave danger to their health, as block stairs or fields.

The phenomenon of children abandonment is not singular, [1], [2], but Romania has specific characteristics as a result of the Communist period, in which because of the pro-birth policy, child abandonment has become a prominent phenomenon of history. In the years following the Romanian Revolution from 1989, the situation of the orphanages in Romania was captured in images by foreign reporters and made know to the world. In Romania of the 19th century, "the sudden and temporary increase of fertility was followed

Manuscript received November 30, 2014; revised January 21, 2015. This paper was co-financed from the European Social Fund, through the Sectorial Operational Programme Human Resources Development 2007-2013, project number POSDRU/159/1.5/S/138907 "Excellence in scientific interdisciplinary research, doctoral and postdoctoral, in the economic, social and medical fields - EXCELIS", coordinator The Bucharest University of Economic Studies".

Rebeca Scorcia Popescu is with the Faculty of Sociology and Social Work, University of Bucharest, 9, Schitu Măgureanu Street, district 5, Bucharest, Romania (e-mail: rebecapopescu@yahoo.com). by a large increase in the number of abandon children in orphanages that were meant to shelter them and whose fate worthy of pity was discovered by Western countries on the occasion of the fall of communism," [2].

The situation of Romanian children from Communist period was presented in details by Kligman [3] and others authors.

In the 2000s the Romanian legislation was changed and reflected the interest for diminishing child abandonment and deinstitutionalization [4]-[6].

Once the Law no. 272/2004 has been established, the alternative measures of protection designed to facilitate keeping the child in the family have been completed According to article 55 of Law no. 272/2004 on the protection and promotion of the rights of the child, the State grants special protection to "a child temporarily or permanently deprived of the protection of his parents until a full exercise capacity acquisition" [7]. According to article 64 from the same Law, the child under two years old can be placed "only at extended family or foster family, his/her placement in a residential care service being prohibited", with the exception of children with disabilities. Also, according to the same article, the State should keep siblings together.

\section{InSTITUTIONALIZATION CONSEQUENCE}

The institutionalization consequence for children, especially for the ones that were raised in Romanian communist orphanages, was the subject for many researches. [8]-[11].

Longitudinal studies carried out in Bucharest, as part of The Bucharest Early Intervention Project (http://www.bucharestearlyinterventionproject.org/), which began in 1999, 10 years after the Romanian Revolution, pointing out problems with the physical and social health of the institutionalized children: delays, anxiety disorders, attention deficit, repetitive behaviors, issues of attachment and low intelligence. The adverse effects of the placement, the residential treatment, as well as the risk to escape from the institution - loitering, departure from the system of protection without education or employment, loosing opportunities to gain significant work experience - has often been criticized for excessive use [12].

Also, there are other reactive negative consequences: hospital staff rejection, rehabilitation difficulties when returning home, vulnerability in terms of attachment. „The early experience remains a fundamental element in perpetual 
motion and it influences the development array of a person." [14].

\section{RESEARCH METHOD}

This study uses secondary analysis of the data from the period 2003-2013 for children aged between 0 and 3 years old, abandoned in different hospital units, institutionalized in public orphanages or public and private foster care institutions. The data were taken from the website of the Romanian Ministry of Labor, Family and Social Protection. (http://www.copii.ro/alte_categorii.html).

It was envisaged that 0-3 years old children represent the most vulnerable category in terms of long-term consequences of institutionalization and from the point of view of the future family reintegration possibilities and regarding the serious attachment disorders.

TABLE I: ChILdRen 0 - 6 YeARs Old, In PUBlic Foster CARE Centers DURING THE PERIOD 2003-2013

\begin{tabular}{|c|c|c|c|c|}
\hline & $\begin{array}{l}\text { Under } \\
\text { year }\end{array}$ & 1 1-2 years & $3-6$ years & Total \\
\hline 2003 & 619 & 889 & 1730 & 32171 \\
\hline 2004 & 468 & 541 & 1552 & 27579 \\
\hline 2005 & 123 & 323 & 1395 & 23684 \\
\hline 2006 & 98 & 250 & 1269 & 21198 \\
\hline 2007 & 226 & 316 & 1492 & 20532 \\
\hline 2008 & 236 & 332 & 1521 & 20033 \\
\hline 2009 & 232 & 343 & 1476 & 19525 \\
\hline 2010 & 246 & 395 & 1541 & 19126 \\
\hline 2011 & 260 & 427 & 1608 & 19215 \\
\hline 2012 & 257 & 421 & 1702 & 18793 \\
\hline 2013 & 273 & 425 & 1687 & 18148 \\
\hline
\end{tabular}

Source: Ministry of Labor, Family and Social Protection, http://www.copii.ro/Statistici, * the data were subjected to secondary examination, being included in the table above only data relating to children and young persons placed in public institutions in December of each year. For the years 2003 and 2004 have used only data from November, because December has not been identified. Were not included in the table those who are placed at foster parents, relatives, or in private centers.

TABLE II: NUMBER OF CHILDREN BY AGE GROUP (YEARS OLD) IN ROMANIAN RESIDENTIAL SERVICES-IN DECEMBER 2013

\begin{tabular}{lllll}
\hline \hline Care & Under & $1-2$ & $3-6$ & Total \\
Institutions & 1 year & years & years & \\
\hline Public & 273 & 425 & 1687 & 18148 \\
Private & 9 & 48 & 460 & 4041
\end{tabular}

Source: Ministry of Labor, Family and Social Protection, http://www.copii.ro/Statistici.

TABLE III: THE SITUATION OF CHILDREN WHO WERE ABANDONED/LEAVED IN HOSPITAL UNITS, IN 2013

\begin{tabular}{|c|c|}
\hline $\begin{array}{l}\text { The number of children abandoned in the } \\
\text { maternity hospitals and other medical units in } \\
\text { the January-December } 2013 \text { of which: }\end{array}$ & 1449 \\
\hline Abandoned in maternity units & 915 \\
\hline Abandoned in pediatric units & 450 \\
\hline Abandoned in other medical units & 84 \\
\hline
\end{tabular}

\section{Results}

The total number of institutionalized children decreased in a constant manner from 32171 in 2003, until 18793 in 2013.

Also, the number of 0-3 year old children from public orphanages has decreased steadily from 2003 to 2006 , standing out the deinstitutionalization efforts and measures taken to promote the maintaining of the family ties and to prevent child abandon, in accord with the Law 272 from 2004.

In fact the measures taken after the 1990s have led to a decrease in the number of 0-3 years children from the Public Placement Centers, until the year 2006. Later the number of 0-3 year old children from the Public Placement Centers recorded a slight increase, which, however, remains on an annual basis (Table I).

The number of children 0-3 year old from Private Placement Centers was small compared with the ones from Public Care Institutions (Table II). The majority of small children without their parents care are usually residents in public centers.

If we analyze the situation of institutionalized 0-3 year old children, compared to the total number of children in Public Orphanages, we can identify that, as a percentage, the number of children remains fairly constant within the range examined.

Thus, in 2013, $4 \%$ of the total number of children in public foster care institutions, was represented by children under 3 years old (see Fig. 1), and in 2003, a rate of 5\% of the total number of children in public foster care institutions, was represented by children under 3 years (see Fig. 2). In 2006, when it was recorded the lowest number of institutionalized 0-3 years children in Public Care Centers, they were in total 348 , representing $1.6 \%$ of the total of 21.198 children from Public Centers (Table I).

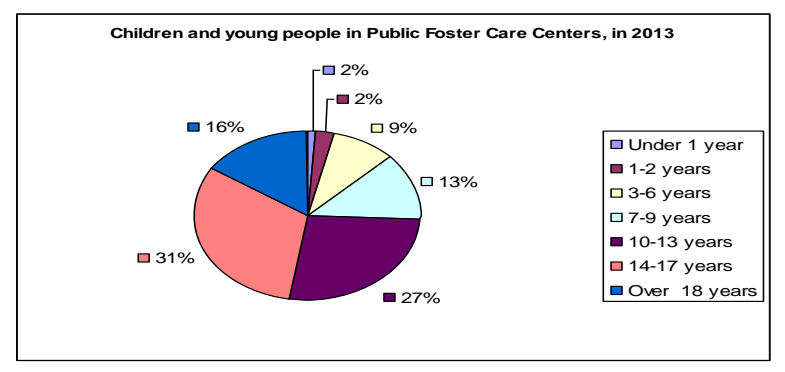

Fig. 1. Children and young people in public foster care centers, in 2013.

The global economic situation had led to poverty and from 2006 the percentage of $0-3$ years abandoned children had increased from $1.6 \%$, in 2006 to $4 \%$ in 2013 . The response to poverty meant the abandonment of children, or more elegant said, leaving them in hospital units, from their birth (Table III).

\section{Discussions}

In a social context that still needs to face the communist history of abandoned children, the reaction of the population to the challenges of family growth with one or more unwanted children was not to assume the responsibilities that came with the job of being parent. 


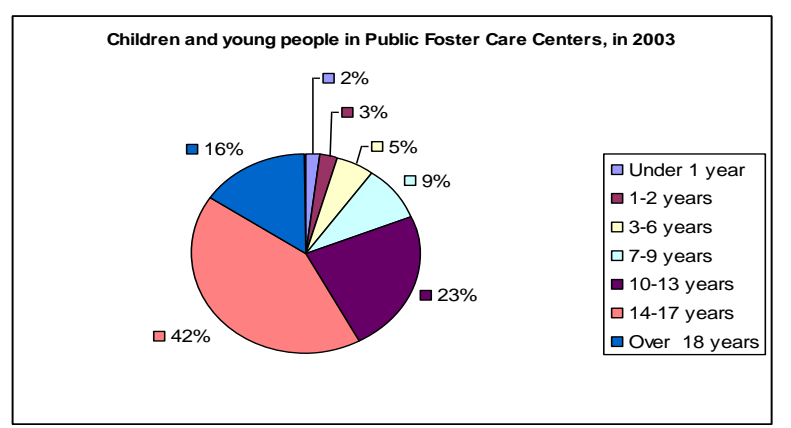

Fig. 2. Children and young people in public foster care centers, in 2003.

According to The Social Learning Theory, the person learns in his social experiences, by direct observation or through experiment [15]. Because of the fact that child abandon was not considered a problem, during and after Romanian Revolution from 1989, the idea that it is not a problem if the poor parent leaves their children in hospital units or Placement Care Institutions was common. This has happened in different countries in $19^{\text {th }}$ century as well [16], [17].

In Romania, the abandonment remains an extreme form of parental negligence, represent a rudimentary way of solving the problem of "unwanted children" or unaccepted for cultural or economic reasons and continues to be a common practice, "at least one out of one hundred children being abandoned in maternity" [18]. Data regarding the abandonment of children in maternity, available on the website of the Ministry of Labor show that indeed there are still newborns left in the hospital immediately after birth. In 2013 there were 915 children left in maternity, representing a rate of $63 \%$ of the total children left temporarily in the Romanian hospitals (Table III). This meant that each day 2,5 new-born children were abandoned in maternities in 2013.

Although new-born abandoned in Maternities should be placed in a foster family or to relatives, still some of them were placed with their siblings in different institutions. The data show that the number of 0-3 year old children placed in public residential institution was 1508 in 2003, 1009 in 2004, 446 in 2005, after the Law. 272/2004 was published, 348 in 2006 and the number steady increase being 698 in 2013 (Table. I).

In 2013 there were 915 new-born children abandoned in maternities (Table. III), out of which 273 0-1 year old children were in Public Residential Institution (Table I). Although the 273 children had siblings placed in institution or disabilities, the main goal should be for them to be raised and spend time in a family.

\section{CONCLUSIONS}

It is necessary to promote prevention of institutionalization of abandoned children and especially the need to support the family/mother in order to maintain family ties.

Although the parents justify their own child abandonment with poverty, this should be changed, because of the institutionalization effects. Although Goffman excludes orphanages and Foster Places on the list of total institutions, he appreciates at the same time that "if the institution period is long it may occur what was called acculturation characterized by dispossession of roles, the lack of boundaries between the spheres of everyday life, sleep, daily activities that take place in the same institution, the lack of personal belongings, the lack of strategies for primary or secondary adapting, solidarity, limited cooperation, situational withdrawal." [19].

Abandoned children and institutionalized for long periods, integrate with difficulty in society, and many of them do not return into the origin family, the parents do not assume the parent role subsequent the abandonment.

It is also necessary to promote alternative measures of children protection in difficult situations, like the Maternal Centre, the Day Care Centre and also Adoption. The first two would allow the parents to assume the role and parent responsibilities. Also, the Maternal Center is the only residential institution of whose services can benefit the child and his mother together, a fact that ensures a proper relationship between them, designed to facilitate the formation of parental autonomy and preventing child abandonment.

Abandon prevention policies may be found in subsequent years in the increasing number of centers specialized in educating and working with parents/mother and child, like Maternal Centers, Day Centers and Centers/offices for counseling parents and children; and the success of these policies means steady decrease in the number of children abandoned in hospitals or placed in public foster care centers.

\section{ACKNOWLEDGMENT}

The author reports no conflict of interest. This paper was co-financed from the European Social Fund, through the Sectorial Operational Program for Human Resources Development 2007-2013, project number POSDRU/159/1.5/S/138907 "Excellence in scientific interdisciplinary research, doctoral and postdoctoral, in the economic, social and medical fields - EXCELIS", coordinator The Bucharest University of Economic Studies".

\section{REFERENCES}

[1] N. S. Gill. Roman Exposure of Infants, Selling children -Human Alternative to Abandoning, Abortion or Killing. [Online]. Available: http://ancienthistory.about.com/od/familyanddailylife/qt/072707expos ure.htm

[2] M. Segalen, "Sociologia familiei," The Sociology of the Family, Iaşi: Polirom, p. 366, 2011.

[3] G. Kligman. "The Politics of Duplicity Controlling Reproduction in Ceausescu's Romania, University of California Press, Bucureşti: Humanitas, 2000.

[4] G. Batculescu and M. Tofan, "Regulatory and practical aspects relating to the protection of children in Romania," Journal of Social Economy, vol. III, no. 4, pp. $85-97,2013$

[5] S. Radulescu, "The evolution of legislation in children protection and welfare in Romania," Romanian Journal of Sociology, no. 3-4, pp. 257-280, Bucharest, 2011.

[6] K. F. Greenwell. Child Welfare Reform in Romania: Abandonment and Deinstitutionalization. [Online]. Available: pdf.usaid.gov/pdf_docs/Pnacn657.pdf

[7] Law no 272 of 21 June 2004 on the Protection and Promotion of Children's Rights, Republished in the Official Journal, no. 159, 2014.

[8] K. Audet and L. L. Mare, "Mitigating effects of the adoptive caregiving environment on inattention/overactivity in children adopted from Romanian orphanages," International Journal of Behavioral Development, vol. 35, no. 2, pp. 107-115, September 2010.

[9] P. J. Marshall and N. A. Fox, "A comparison of the electroencephalogram between institutionalized and community 
children in Romania," Journal of Cognitive Neuroscience, vol. 16, no. 8, pp. 1327-1338, 2004.

[10] K. A. McLaughlin, C. H. Zeanah, N. A. Fox, and C. A. Nelson. Attachment security as a mechanism linking foster care placement to improved mental health outcomes in previously institutionalized children. Journal of Child Psychology \& Psychiatry. [Online]. 53(1), pp. 46-55. Available: http://www.bucharestearlyinterventionproject.org/Publications.html

[11] R. Popescu. The abandonment of children with 0-3 years in Romania. Institutionalization and Issues. [Online]. Available: http://www.conference/info/ro/

[12] L. Polvere, "Youth perspectives on restrictive mental health placement: unearthing a counter narrative," Journal of Adolescent Research, vol 26, no. 3, pp. 318-343, 2011.

[13] C. A. Roberts and P. R. Messmer, "Unaccompanied hospitalized children: Nurses' search for understanding," Journal of Holistic Nursing, vol. 30, no. 2, pp. 117-126, June 2012.

[14] A. Muntean and A. Munteanu, Violence, Trauma, Resilience, Iasi: Polirom, p. 276, 2011,

[15] A. Muntean and A. Munteanu, Violence, Trauma, Resilience, Iasi: Polirom, 2011, ch.1.

[16] M. Segalen, "Sociologia familiei," The Sociology of the Family, Iaşi: Polirom, 2011.

[17] R. Gilligan and E. Munro, "The 'dance' of kinship care in England and Ireland: Navigating a course between regulation and relationships," Psychosocial Intervention, vol. 22, no. 3, pp. 185-192, October 2013.

[18] E. Bonchiş, "Familia și rolul ei în educarea copilului," Family and Its Role in Children Education, Iaşi: Polirom, p. 383, 2011.

[19] E. Goffman, "Aziluri Eseuri despre situatia socială a pacientilor psihiatrici şi a altor categorii de personae instituţionalizate," Translated from Asylum: Essays on the Social Situation of Mental Patients and other Inmates, Iaşi: Polirom, p. 63, 2004,

[20] S. Chelcea, "Metodologia cercetării sociale, metode cantitative si calitative, Ediția a treia," Social Research Methodology, Quantitative and Qualitative Methods, București: Economică, 2007.

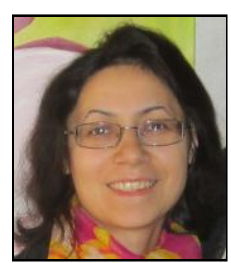

Rebeca Scorcia Popescu lives in Romania and she is a $\mathrm{PhD}$ candidate in sociology, in the Faculty of Sociology and Social Work, University of Bucharest, with a grant ph.D Scholarship "EXCELIS", project number POSDRU/159/1.5/S/138907. She graduated with the master of counseling in social work in 2007 , Faculty of Sociology and Social Work, University of Bucharest and she is licensed in social work-faculty of Baptist Theology in 2001, University of Bucharest.

Rebeca is a social work practitioner, with over 13 years experience in working with risk groups, such as street children, single-parent families, juvenile offenders and not only. She worked as an operator interview-in the reproductive health survey training and field work, conducted by the centers for disease control and prevention, division of reproductive health, 1999 and has supported training courses for social workers from the Dâmbovița County, Romania.

Mrs. Rebeca Popescu is a probation officer, in Dâmbovita County, Romania, where she worked since 2007. Also she is a principal social worker in Romanian National College of Social Workers.

Her research interests include the abandonment of children, mother-child couple, the effects of institutionalization, delinquency, probation. 